\title{
The Social Competence Examined: A Case Study on Parenting and Emotional Development in Children
}

\author{
W. P. Saroinsong ${ }^{\mathrm{a}, 1}$, N. D. Simatupang $\mathrm{g}^{\mathrm{b}, 2}$ \\ ${ }^{a}$ Central China Normal University, Wuhan, China \\ ${ }^{\mathrm{b}}$ Universitas Negeri Surabaya, Surabaya, Indonesia \\ 1wpatria16@gmail.com
}

\begin{abstract}
This study aimed to analyze the effect of parenting and socio-emotional development to social skill in early childhood in B group at Restu I Malang kindergarten. The data was collected through questionnaires and checklists. This study used a quantitative method with multiple regression and compare mean (one-way ANOVA) to analyze the data. The results showed that parenting and socio-emotional development partially influenced the children's social skills, and there was no significant difference in children's social skills between the parenting parents authoritarian, permissive parenting, and parenting democratic.
\end{abstract}

Keywords-Parenting; emotional development; children;

\section{INTRODUCTION}

In the era of globalization, we have entered into the demands of a free competition. Human beings in order to become a good leader in competition must balance the intelligence with the socio-emotional aspects. Furthermore, the need for the router generation is to have a good and strong personality and good mental resilience (hardiness). A strong mental endurance is characterized by the ability of individuals to be able to face various problems and solve them properly, in other words, an individual must be able to survive and have the existence of life. There are at least five developments in the early childhood, but the most difficult one for a child is learning to connect emotionally with their parents, siblings, and others. It is suggested as one of the critical skills to be mastered children in early childhood (preschool), a social skill [15]. By developing these skills early on, would allow children to develop normally and balance in fulfilling the tasks in the future developments adolescence (Hurlock, 1997).

Supporting the individual's success in life, the early childhood needs to master a wide range of capabilities, especially social skills [18]. The success of one's life is determined by social skills. Moreover, the basis for developing the children's abilities to interact with the macro environment is by comparing their social skills with their intellectual ability [20]. Goleman in his research found that someone who has a ratio of $20 \%$ to $80 \%$ of IQ and EQ would support its success. It means that the EQ (Emotional Quotient) is a factor that dominates more than the IQ (Intelligence Quotient). Emotional intelligence has psychological constructs as part of four sub-constructs that is a social skill (Goleman, 1997; Goleman, 2006). Berk (2004) emphasized that the importance of social context is for children's learning process and experience in their social interaction, as the instrument to develop their ability.

Vygotsky (1963) explained that the forms of mental activity derived from the social and cultural context when children interact with the people around them. The development of children includes social relations that occur in an environment where children hang out.

Another study examined that the form of the social skills for the preschoolers, among others, foster and respond to the interpersonal relationship with other children satisfactorily, not in the form quarrelling or being selfish, but in the form of sharing things they have like cakes and toys. Thus, the social skills of children need to be controlled because it will equip them to come to the wider social life. Social problems in kindergarten can be identified from a variety of behaviors that revealed by the children, namely be selfish, be aggressive, be introvert, be unsocial, high-tempered, and defying even withdraw from their environment. On the social skills, it becomes a crucial issue to be discussed and examined so that it can be constructed and developed for better children's social skills (Moeslichatun, 1996).

The importance of social context for children's learning process and experience in their social interaction is the instrument to develop the children's abilities to think. Vygotsky also explained that the forms of mental activity derived from the social and cultural context where children interact thus to understand the development of the children, adults are required to understand the social relations that occur in an environment where children hang out (Berk, 1997; Powell \& Karina, 2009).

There are some factors affect the child's social skills, namely gender, age and stage of development as well as the environment. Social skills developed through the process of learning by the individuals in their interactions with the environment, for instance, the interaction between parents and their children [16]. It is because the child's social sensitivity started from the family then undergoes a transition to the school environment. The lack of developed social skills on children is often because the adults around children rarely provide stimulus and reinforcement for them. Early childhood education should cover the whole process of stimulation of social interaction, and it is not limited to the process of 
learning that takes place in educational institutions that simply prioritize the cognitive aspects to the progression of the child. This would suggest that early childhood education could take place at any time as well as a human interaction that occurs within the family, peers, and of the social relations that correspond to the conditions of early childhood development (Adiyanti, 2001).

When the children stepped on preschool stage, it is the time that the children are ready to identify the world outside itself, readiness to share and reduced dependence on adults to provide guidance and meet their needs for friendship and then kids are ready to connect to each other [17]. On the one hand, during early childhood, parents remain the most important socialization agent while on the other side of preschool children in need of companionship and making every effort to meet their needs (Cohen \& Rudolph, 1977).

The effect of breastfeeding and psychosocial stimulation of the socio-emotional development of children under-five in your mother's working and not working. The results showed that psychosocial stimulation becomes one of the dominant factors affecting the socio-emotional development of children. In addition, the emotional development of children is also affected by the age of the child (Nurani, 2002).

The development goes in stages based on the age and the results of regression showed that the score of each additional unit would increase the child's age score of 0.218 units' emotional development of children. For the age of the child will determine the level of emotional maturity so that children who have normal emotional development in accordance with the stages will have high social skills to socialize with their surroundings (Erikson, 1993). On early childhood, emotional problems could be observed from the results of a survey conducted by Izzaty (2005) in kindergarten in Yogyakarta. These results indicate a general problem that often encountered is aggressiveness, anxiety, temper tantrums, difficulty concentrating, stuttering or difficulties.

\section{Hypothesis of the Study}

- The parenting given by the parents gives a significant effect on children's social skills.

- The development of socio-emotional aspects gives a significant effect on children's social skills.

- The pattern of parenting and the development of the socioemotional give a significant effect on the early childhood social skills simultaneously.

- There is a significant difference between the parenting parents authoritarian, permissive parenting, and parenting democratic to children's social skills.

\section{METHOD}

\section{A. Participant}

The sample in this study uses a simple random sampling with the calculation of Slovin formula [14]. The population of 129 children was randomly assigned proportionally and taken only about 120 samples in order to meet the minimum required a number of samples. The participant includes 120 children and parents in Restu Kindergarten at Malang Indonesia with ages ranging from 5-6 years.

\section{B. Materials}

This field research uses questionnaires that distributed based on the list of statements made by the parents of children in B group Restu I in Klojen Malang. The variables of this study are measured using a Likert scale, with the size of the interval where the scale with the size of the interval can be used to measure the achievement test, measuring intelligence, and attitude. This questionnaire aims to obtain the correlation and regression data of the three variables in order to test the hypothesis, for the questionnaires used are closed that the statements made in such a way until the respondent is limited in giving answers to some alternative alone or with only one answer. The participant was instructed to rate their parenting on a scale from 1 (not strongest agree ) to 4 (strongest agree).

\section{Procedure}

Before the instruments granted to the respondents, the first instrument tested to the subject of the trial, in this case the instrument parenting parents a questionnaire that tested prior to 40 parents of children attending the kindergarten and Restu I Malang and to five classes each 8 parents taken as a representative sample to be tested and the test samples are taken randomly. After meeting the requirements of validity and reliability, the instrument spread to the actual sample size of 120 respondents. The research instrument in variable socioemotional development and social skills of children in the form of observation sheets, validated by expert lecturers and adjusted to the conditions and characteristics of children based on interviews with teachers and preliminary observations in kindergarten Restu I Malang. A test instrument made against the same sample numbering 40 children. 8 children taken from each class randomly. After the validity of the instrument meets the standard numbers on statistical values, the instrument is measured at 120 children.

\section{RESULTS AND DISCUSSIONS}

TABLE I. PARTIAL REGRESSION ANALYSIS FOR PARENTING AGAINST CHILDREN'S SOCIAL SKILLS

\begin{tabular}{|c|c|c|c|c|c|c|}
\hline \multicolumn{2}{|c|}{ Model } & \multicolumn{2}{|c|}{$\begin{array}{c}\text { Unstandardized } \\
\text { Coefficients }\end{array}$} & $\begin{array}{c}\text { Standardized } \\
\text { Coefficients }\end{array}$ & T & Sig. \\
\cline { 3 - 7 } \multicolumn{2}{|c|}{} & B & $\begin{array}{c}\text { Std. } \\
\text { Error }\end{array}$ & Beta & & \\
\hline \multirow{2}{*}{1} & (Constant) & .654 & .369 & & 1.770 & .080 \\
\cline { 2 - 7 } & $\log 1$ & .350 & .132 & .279 & 2.650 & .009 \\
\cline { 2 - 7 } & $\log 2$ & .312 & .120 & .275 & 2.607 & .010 \\
\hline
\end{tabular}

TABLE II. PARTIAL REgRESSION ANALYSES FOR SOCIO-EMOTIONAL DEVELOPMENT AGAINST CHILDREN'S SOCIAL SKILLS

\begin{tabular}{|c|c|c|c|c|c|c|}
\hline \multicolumn{2}{|c|}{ Model } & \multicolumn{2}{|c|}{$\begin{array}{c}\text { Unstandardized } \\
\text { Coefficients }\end{array}$} & $\begin{array}{c}\text { Standardized } \\
\text { Coefficients }\end{array}$ & \multirow{2}{*}{ Sig. } & \\
\cline { 3 - 5 } \multicolumn{2}{|c|}{} & B & $\begin{array}{c}\text { Std. } \\
\text { Error }\end{array}$ & Beta & & \\
\hline \multirow{2}{*}{1} & (Constant) & .654 & .369 & & 1.770 & .080 \\
\cline { 2 - 7 } & $\log 1$ & .350 & .132 & .279 & 2.650 & .009 \\
\cline { 2 - 7 } & $\log 2$ & .312 & .120 & .275 & 2.607 & .010 \\
\hline
\end{tabular}


TABLE III. REGRESSION ANALYSES SIMULTANEOUS FOR PARENTING AND SOCIOEMOTIONAL DEVELOPMENT OF THE CHILDREN'S SOCIAL SKILLS

\begin{tabular}{|c|c|c|c|c|c|c|}
\hline \multicolumn{2}{|c|}{ Model } & $\begin{array}{c}\text { Sum of } \\
\text { Squares }\end{array}$ & df & $\begin{array}{c}\text { Mean } \\
\text { Square }\end{array}$ & F & Sig. \\
\hline \multirow{2}{*}{1} & Regression & 14.967 & 2 & 7.483 & 16.991 & $.000^{\mathrm{b}}$ \\
\cline { 2 - 8 } & Residual & 46.246 & 105 & .440 & & \\
\cline { 2 - 8 } & Total & 61.213 & 107 & & & \\
\hline
\end{tabular}

The results of the current research showed a significant effect of parenting effect to the child's social skills in kindergarten Restu I Malang with a beta value of 0.350 and the probability of 0.009 . This suggests that each additional value on parenting will give a score of 0.350 on the social skills of children. Means the better parenting parents the child's social skills will be higher as well. The concept of thinking of parents who provide a decent education for their children, expecting school as the best place means of education can be a tool to develop the potential of children, especially basic attitude and personality of the child. But parents still perform its functions in kindergarten Restu I Malang. This is indicated by the beta value for 0.312 and 0.010 does increased probability of a value on the socioemotional development would give a value of 0.312 on social skills and socio-emotional development of the skills effect social child has the meaning of 0010. Under these conditions, if the child's development in socio-emotional aspects develops normally in accordance with the stages of his age would give a positive improvement in the child's social skills.

\section{CONCLUSION}

Crain (2007) suggests that developmentally age and maturity of the child's biological determine child's abilities to socialize with family, teachers, friends and the surrounding environment. A child at the age of 5-6 years has been able to socialize with the environment, because in fact the development of children pass through the same sequence, but it has variations in the growth rate so that the cultures in society needs to adopt the uniqueness of the child.

\section{REFERENCES}

[1] Berk, L. (1997). Child development (4th ed.). Boston: Allyn \& Bacon.

[2] Berk, L.E. (2004). Awakening children's minds: How parents and teachers can make a difference. Oxford University Press.
[3] Cohen, D.H., \& Rudolph, M. (1977). Kindergarten and early schooling. New Jersey: Prentice-Hall Inc.

[4] Crain, W. (1992). Concept and application, theories of development concepts and application. New Jersey: Prentice Hall

[5] Erikson, E. H. (1993). Childhood and society. Oxford University Press.

[6] Goleman, D. (1997). Emotional intelligence. Jakarta: PT. Gramedia Pustaka Utama.

[7] Hastuti, D. (2006). Analisis pengaruh model pendidikan prasekolah pada pembentukan anak sehat, cerdas dan berkarakter [disertasi]. Bogor: Fakultas Pertanian, Institut Pertanian Bogor.

[8] Hurlock, E. B. (1997a). Psikologi perkembangan: Suatu pendekatan sepanjang rentang kehidupan (A. Dharma, Ed). Jakarta: Penerbit Erlangga.

[9] Hurlock, E. B. (1997b). Perkembangan anak (A. Dharma, Ed). Jakarta: Penerbit Erlangga.

[10] Izzaty, R. E. (2005). Mengenali permasalahan perkembangan anak usia taman kanak-kanak. Buku Ajar Bidang PGTK. Jakarta: Direktorat Jenderal Pendidikan.

[11] Nuraeni. (2006). Pengaruh pola asuh orang tua terhadap pembentukan kepribadian anak taman kanak-kanak, Tugas Akhir Universitas Negeri Semarang. On line: http://digilib.unnes.ac.id/gsdl/collect/skripsi.1/tmp/2383.html (Accessed 1 Januari 2012).

[12] Moeslichatun. (1999). Metode pengajaran di taman kanak-kanak. Jakarta: Rineka Cipta.

[13] Vygotsky, L. S. (1963). Learning and mental development at school age (J. Simon, Trans.). In B. Simon \& J. Simon (Eds.), Educational psychology in the U.S.S.R. (pp. 21-34). London: Routledge \& Kegan Paul.

[14] Tejada, J. J., \& Punzalan, J. R. B. (2012). On the misuse of Slovin's formula. The Philippine Statistician, 61(1), 129-136.

[15] Krogh, S. L., \& Slentz, K. L. (2010). Early childhood education: Yesterday, today, and tomorrow. Routledge.

[16] Peisner-Feinberg, E. S., Burchinal, M. R., Clifford, R. M., Culkin, M. L., Howes, C., Kagan, S. L., \& Yazejian, N. (2001). The relation of preschool child-care quality to children's cognitive and social developmental trajectories through second grade. Child development, 72(5), 1534-1553

[17] Phillips, D. A., \& Shonkoff, J. P. (Eds.). (2000). From neurons to neighbourhoods: The science of early childhood development. National Academies Press.

[18] Powell, K. C., \& Kalina, C. J. (2009). Cognitive and social constructivism: Developing tools for an effective classroom. Education, 130(2), 241-251.Eccles, J. S. (1999). The development of children ages 6 to 14. The future of children, 30-44.

[19] Goleman, D. (2006). Emotional intelligence. Bantam.

[20] Wentzel, K. R. (1991). Social competence at school: Relation between social responsibility and academic achievement. Review of educational research, 61(1), 1-24. 